\title{
Direct Design of T-Beams for Combined Load of Bending and Torsion
}

\author{
A. S. Alnuaimi*, K.S. Al-Jabri and A.W. Hago \\ Department of Civil and Architectural Engineering, Sultan Qaboos University, P.O. Box 33, Al Khodh 123, Muscat, Oman
}

Received 22 November 2005; accepted 24 April 2006

التصميم الباهر البيزاة ذوات الثفة المبرنة لامطال الانمثاء والالتواء

علي النعيبي و خليفه الجابري وعبدالواحد هجو

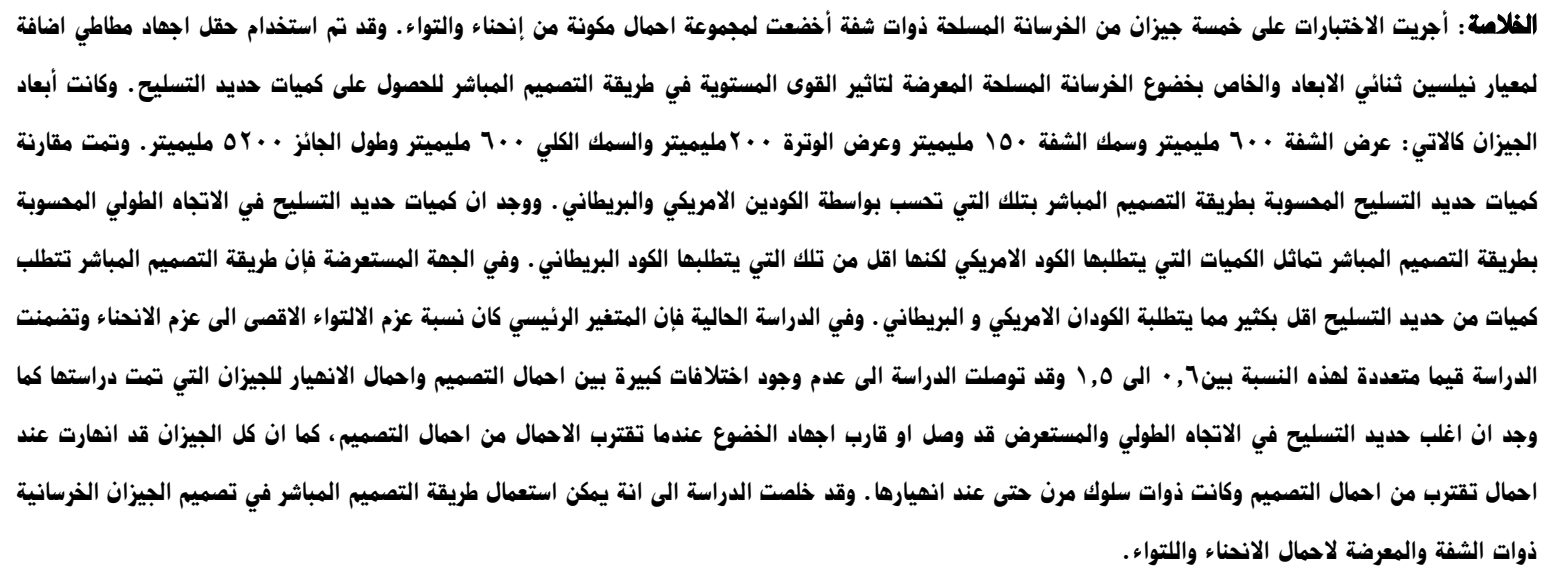

الهزردات الهنتاهية: الجيزان ذوات الثفة، طريقة التصميم الهباشر ، انحناء، اللتواء، الخرسانة البسلحة.

\begin{abstract}
Tests were conducted on five reinforced concrete T-beams subjected to combined load of bending and torsion. Elastic stress field in conjunction with Nielsen's 2D yield criterion for reinforced concrete subjected to in-plane forces were used in the Direct Design Method for the design of reinforcement. The beam dimensions were: flange width $=600 \mathrm{~mm}$, flange thickness $=150 \mathrm{~mm}$, web width $=200 \mathrm{~mm}$, total depth $=600 \mathrm{~mm}$ and beam length $=5.2 \mathrm{~m}$. Required reinforcement calculated using the Direct Design Method was compared with the ACI and BSI codes. It was found that the Direct Design Method requires longitudinal reinforcement similar to the ACI code but less than the BSI code. In the transverse direction, the Direct Design Method requires much less reinforcement than both codes. The main variable studied was the ratio of the maximum twisting moment to the bending moment which was varied between 0.6 and 1.5. Good agreement was found between the design and experimental failure loads. Most of the longitudinal and transverse steel yielded or reached near yield stress when the design load was approached. All beams failed near the design loads and undergone ductile behaviour until failure. The results indicate that the Direct Design Method can be successfully used to design reinforced concrete T-beams for the combined effect of bending and torsion loads.
\end{abstract}

Keywords: T-beams, Direct design method, Bending, Torsion, Reinforced concrete

\section{Notations}

$\mathrm{A}_{\mathrm{c}} \quad$ gross area of the whole cross-section

$A_{0} \quad$ area of the cross-section enclosed by the shear flow centreline

$\mathrm{A}_{\mathrm{x}}, \mathrm{A}_{\mathrm{y}} \quad$ steel areas per unit width in $\mathrm{x}$ and $\mathrm{y}$ directions respectively

E Young's modulus of elasticity

$\mathrm{f}_{\mathrm{cu}} \quad$ concrete cube compressive strength

$\mathrm{f}_{\mathrm{sx}} \quad$ steel stress in the longitudinal direction

$\mathrm{f}_{\mathrm{sy}} \quad$ steel stress in the transverse direction

$\overline{\text { *Corresponding author’s e-mail: alnuaimi@squ.edu.om }}$ 
$\mathrm{f}_{\mathrm{y}} \quad$ yield strength of longitudinal steel

$\mathrm{f}_{\mathrm{yv}} \quad$ yield strength of transverse steel

I moment of inertia of the section

L.F. $\quad$ load factor $=\left(\mathrm{T}_{\mathrm{i}} / \mathrm{T}_{\mathrm{d}}+\mathrm{M}_{\mathrm{i}} / \mathrm{M}_{\mathrm{d}}\right) / 2$ at any load increment $i$

$\mathrm{L}_{\mathrm{e}} / \mathrm{L}_{\mathrm{d}} \quad$ failure load ratio $=\left(\mathrm{T}_{\mathrm{e}} / \mathrm{T}_{\mathrm{d}}+\mathrm{M}_{\mathrm{e}} / \mathrm{M}_{\mathrm{d}}\right) / 2$ for the last (failure) load increment

$N_{1} \quad$ concrete resisting force in the principal direction $1,\left(=\sigma_{1} \mathrm{t}\right)$

$N_{2} \quad$ concrete resisting force in the principal direction $2,\left(=\sigma_{2} \mathrm{t}\right)$

$N_{\mathrm{x}} \quad$ applied in-plane force per unit length in the $\mathrm{x}$ direction on a element with thickness $t,\left(=\sigma_{\mathrm{x}} \mathrm{t}\right)$

$N_{\mathrm{xy}} \quad$ applied in-plane shear force per unit length on a element with thickness $t,\left(=\tau_{\mathrm{xy}} \mathrm{t}\right)$

$N_{\mathrm{y}} \quad$ applied in-plane force per unit length in the y direction on a element with thickness $t,\left(=\sigma_{\mathrm{y}} \mathrm{t}\right)$

$N_{\mathrm{y}}^{\mathrm{s}} \quad$ resisting forces in $\mathrm{x}$ direction steel $\left(=\mathrm{A}_{\mathrm{x}} \mathrm{f}_{\mathrm{sx}}\right)$

$N_{\mathrm{y}}^{\mathrm{s}} \quad$ resisting forces in y direction steel $\left(=\mathrm{A}_{\mathrm{y}} \mathrm{f}_{\mathrm{sy}}\right)$

$t \quad$ thickness of the element

$T_{d}, M_{d}$ design torsion and bending moment respectively

$\mathrm{T}_{\mathrm{e}}, \mathrm{M}_{\mathrm{e}}$ experimentally measured torsion and bending moment at failure

$\mathrm{T}_{\mathrm{i}}, \mathrm{M}_{\mathrm{i}} \quad$ experimentally measured torsion and bending moment at load increment $i$

y distance from the neutral axis to the location where stress to be calculated

$\sigma_{1} \quad$ concrete principal stress in direction 1

$\sigma_{2} \quad$ concrete principal stress in direction 2

$\sigma_{\mathrm{x}}, \sigma_{\mathrm{y}}$ applied normal stresses in $\mathrm{x}$ and $\mathrm{y}$ directions respectively

$\varepsilon \quad$ measured steel strain at any load increment $i$

$\varepsilon_{\mathrm{y}} \quad$ longitudinal steel yield strain $\left(=\mathrm{f}_{\mathrm{y}} / \mathrm{E}\right)$

$\varepsilon_{\mathrm{yv}} \quad$ transverse steel yield strain $\left(=\mathrm{f}_{\mathrm{yv}} / \mathrm{E}\right)$

$\tau_{\mathrm{xy}} \quad$ applied elastic shear stress

\section{Introduction}

The present code design equations for concrete structures (especially for shear and torsion) are largely based on experimental results which lead to continuous changes in the code. Calculation of reinforcement for each load is done separately and then summed algebraically which leads to conservative design.

For combined loading, several interaction theories based on ultimate strength criterion have been developed (ie. theories on Truss-Analogy and Skew-Bending), but the major weakness of this approach lies in the fact that it does not present a general design procedure capable of being applied to design for a given general stress state.

Many researchers investigated the behaviour of reinforced and pre-stressed concrete T-beams under different loading conditions (ie. bending, torsion and shear) and the contribution of the sections' elements (ie. flange and web) on resisting applied forces has been also reported. The experimental behaviour of twenty six reinforced concrete T-beams without web reinforcement under combined bending, shear and torsion was reported by Farmer and Ferguson, (1967). Torque-to-shear ratios of 1.5, 3 and 6 were investigated. Results indicated that span length and cross-sectional warping was not found to influence the behaviour greatly. It also suggested that torsion lowered the shear strength of the beam much less than ordinary plastic theory would suggest. Nawy and Potyondy (1971) studied the flexural cracking behaviour of pre-tensioned Iand T-beams. They tested twenty two I- and T-beams with a span of 9 -ft $(2.74 \mathrm{~m})$ and pre-stressed with $1 / 4$ in
$(6.35 \mathrm{~mm})$ diameter 7 -stranded wires. From the results, it was concluded that the confining reinforcement had no influence on the magnitude of load at first crack and Tsections cracked at a lower load than I-sections. Kirk and Loveland (1972) observed, after testing eighteen unsymmetrical reinforced T-beams under bending and torsion, that the location of longitudinal steel at the top or the bottom of the section can have significant influence on the torsional resistance. The effect of reinforced flanges on the torsional capacity of reinforced concrete T-beams was investigated by Zararis and Penelis, (1986). Eighty two Tbeams with various flange widths and percentages of reinforcement were tested in combined torsion and bending. Results showed that there is significant contribution from the reinforced flanges to the torsional capacity of the Tbeams especially when torsion prevailed. Experimental studies by Kotsovos et al. (1987) also showed that the shear resistance of T-beams with shear-span-to-depth ratios greater than 2.5 is provided by the flange and not as widely accepted by the web. Gurfinkel and Fonseca (1996) investigated the ACI code requirement for additional ductility in the T-beam sections and reported that "There is little justification for code-imposed additional demand on minimum ductility of T-beams sections". Recently experimental investigation was carried out by Rahal and Collins, (2003) in order to evaluate the ACI and AASHTO-LRFD design provisions for combined torsion and shear. It was found that the ACI provisions give very conservative results if the recommended value of 45degree is used for the inclination of the compression diagonals. 
It is clear from the above literature and others that large area of disagreement exists among the researchers on the design of T-beams when shear and torsion are involved. One reason for this disagreement is the fact that the design equations used in the code are not based on sound theoretical principles like the theories of mechanics (ie. Theory of Plasticity).

The Direct Design Method, which is based on the Lower Bound Theorem of the Theory of Plasticity, presents a solution to some of the above pitfalls. This procedure satisfies the fundamental requirements of classical Theory of Plasticity (equilibrium condition, yield criterion and mechanism condition) and it reduces the ductility demand assumed for metals. In contrary to the existing codes of practice, this method precludes the use of empirical equations and therefore, it is less vulnerable to changes and may form a basis for a unified design method.

Previous work by Bhatt and Ebireri (1989) had shown that the 'direct design method' could be applied to the design of hollow and solid beams with square cross-section subjected to combined bending and twisting moments. Alnuaimi and Bhatt (2004a, b) used the direct design method for the design of eight reinforced concrete square hollow beams subjected to combined bending, torsion and shear. The main variables studied were the ratio of twisting moment to the bending moment and the ratio of the shear stress due to torsion to the shear stress due to shear force. They concluded that the direct design approach used, gave satisfactory results with beams failing within the range of the design loads and behaving in a ductile manner until failure. Many other researchers have successfully used the direct design method for the design of different types of structures (Kemp 1971; Nielsen 1974; Morley 1977; Memon 1984; El-Nuonu 1985; Hago and Bhatt 1986; Abdel-Hafez 1986; El-Hussein 1994; Bhatt and Bensalem 1996a, b; Bhatt and Mousa 1996; and Elarabi 1999).

In this research, the direct design method was used for the design of five reinforced concrete T-beams. The beams were subjected to combined load of bending and torsion. The required reinforcement obtained using the direct design method was compared with that obtained using the ACI (2002) and the BSI (1997) codes.

\section{Research Significance}

A Theory of Plasticity-based, design procedure for the design of reinforced concrete T-beams subjected to combined loading of bending and torsion is presented as replacement for the empirical-based methods used by the codes of practice. The required reinforcement from this procedure, Direct Design Method, is compared with the required reinforcement using the ACI and the BSI codes. Test results from five T-beams designed using the direct design method are presented.

\section{Test Beams}

Five reinforced concrete T-beams were designed for combined action of bending and twisting moments using the direct design method. The beams were $5200 \mathrm{~mm}$ long with overall depth of $600 \mathrm{~mm}$. The dimensions of the Tsection were $600 \times 150 \mathrm{~mm}$ flange and $450 \times 200 \mathrm{~mm}$ web. Table 1 shows loads that each beam was designed to resist. The main variable in this series was the ratio of the design twisting moment to the bending moment, $T_{d} / M_{d}$, which varied between 0.6 and 1.5. Figure 1 shows the geometry and dimensions of the tested beam.

\section{Table 1. Design load combinations}

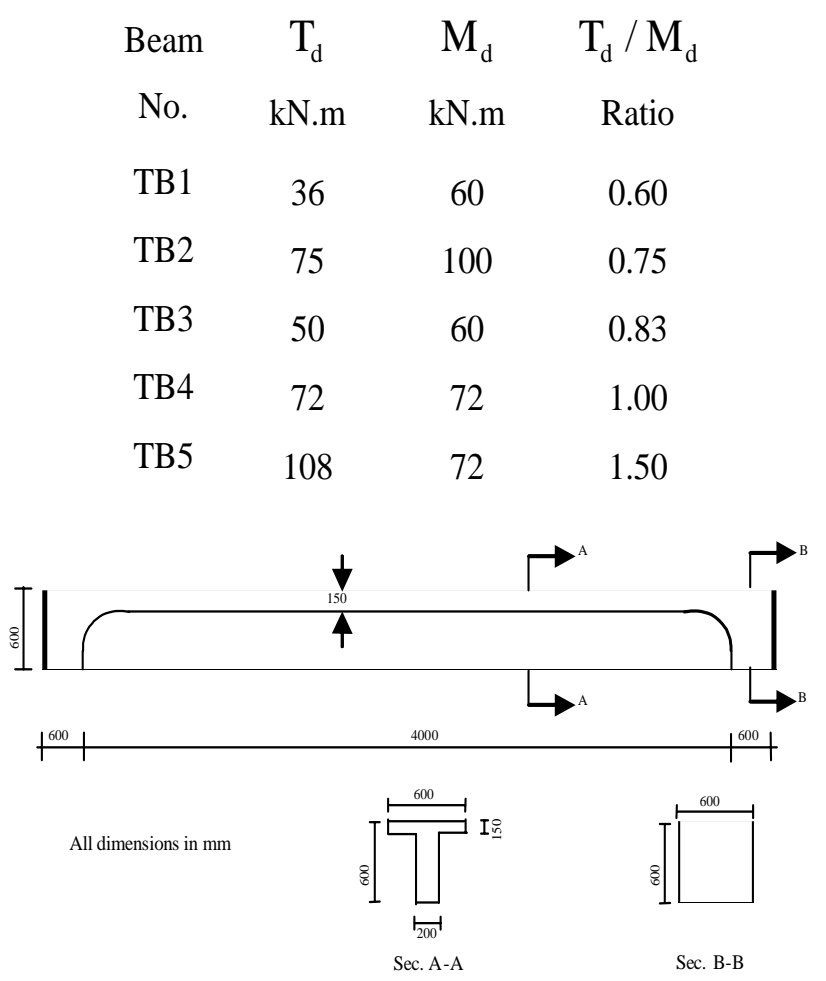

Figure 1. Beam geometry and dimensions

\section{Comparison Between the ACI and BSI Codes and the Direct Design Method}

Table 2 shows the required reinforcement for the Tbeams used in this research based on the ACI and BSI codes and the direct design method, DDM. It can be seen that the direct design approach leads to longitudinal steel requirement close to the ACI code while the BSI code is more conservative. In the transverse reinforcement, the direct design procedure required less reinforcement than both codes in most cases, especially the BSI code. The direct design method was used for the design of this research beams.

\section{Design of T-beams}

The following steps were used for the design of Tbeams, and a numerical example is given in appendix A. Detailed derivation of equations can be found elsewhere Alnuami and Bhatt, (2004a, b). 
Table 2. Required reinforcement using the ACI, BSI and DDM methods

$\begin{array}{ccccccc}\begin{array}{c}\text { Beam } \\ \text { No. }\end{array} & \begin{array}{c}\mathbf{A}_{\mathbf{s}} \\ \left(\mathbf{m m}^{\mathbf{2}}\right)\end{array} & \mathbf{A}_{\mathbf{s v}}\left(\mathbf{m m}^{2} \mathbf{m}\right) & \begin{array}{c}\mathbf{A}_{\mathbf{s}} \\ \left(\mathbf{m m}^{\mathbf{2}}\right)\end{array} & \mathbf{A}_{\text {sv }}\left(\mathbf{m m}^{2} \mathbf{m}\right) & \begin{array}{c}\mathbf{A}_{\mathbf{s}} \\ \left(\mathbf{m m}^{\mathbf{2}}\right)\end{array} & \mathbf{A}_{\mathbf{s v}}\left(\mathbf{m m}^{2} \mathbf{m}\right) \\ \text { TB1 } & 1136 & 914 & 1325 & 978 & 1091 & 606 \\ \text { TB2 } & 1903 & 1848 & 2479 & 1978 & 1908 & 1226 \\ \text { TB3 } & 1484 & 1269 & 1746 & 1358 & 1516 & 842 \\ \text { TB4 } & 1841 & 1741 & 2457 & 1956 & 1932 & 1155 \\ \text { TB5 } & 2633 & 2611 & 3542 & 2934 & 2897 & 1732\end{array}$

1. Calculate the ultimate (factored) design bending moment $\mathrm{M}_{\mathrm{d}}$ and torsion $\mathrm{T}_{\mathrm{d}}$ at the section based on the loading condition, support locations and geometry of the beam.

2. Divide the cross-section into different levels (regions) as shown in Fig. 2.

3. Find the neutral axis, the moment of inertia and the area enclosed by the shear flow centreline .

4. Calculate normal stress $\sigma_{X}$ due to applied load at the centre of each region (level) using elastic stress distribution, $\sigma_{x}=M y / I$.

5. Calculate the shear stresses due to torsion, $\tau_{x y}=\frac{T}{2 t A_{O}}$.

6. Assume $\sigma_{y}=0$ (No out of plane bending is considered).

7. Calculate the ratios $\frac{\sigma_{x}}{\left|\tau_{x y}\right|}$ and $\frac{\sigma_{y}}{\left|\tau_{x y}\right|}$ for each region.

8. Select design equations as explained in the numerical example (Appendix A) .

9. Calculate the required reinforcement.

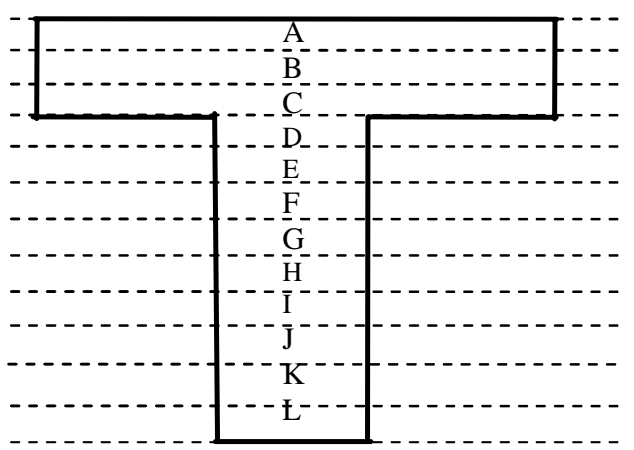

Figure 2. Regions (Levels) in the cross-section

The required reinforcement at mid-span was provided over a test span length of $1200 \mathrm{~mm}$ in the middle of beam. Figure 3 shows typical reinforcement arrangements in a tested T-beam and Fig. 4 shows details of provided reinforcement in the test span of each beam. The solid dots in the figure indicate the locations of bars, which were strain-gauged.

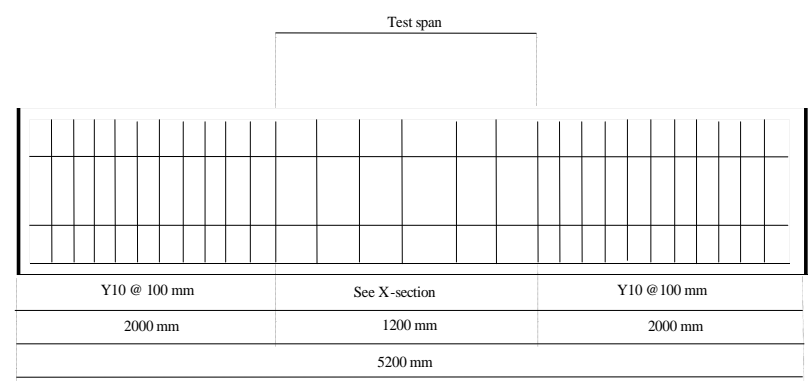

Figure 3. Typical arrangement of reinforcement
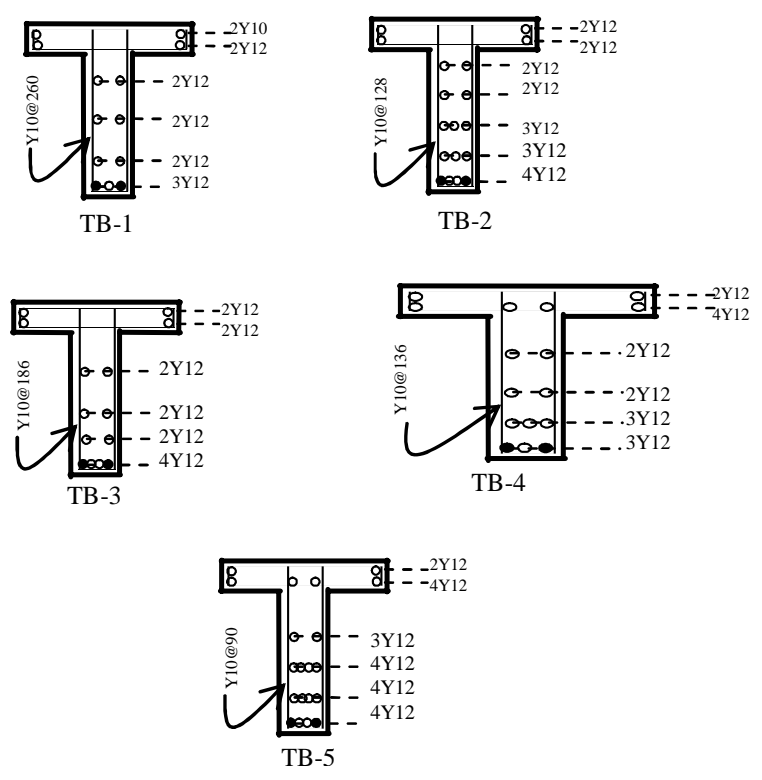

Figure 4. Provided reinforcement at test span

To ensure failure at mid-span, additional reinforcement was provided in the regions outside the test span. Further, to reduce the stresses due to distortion of the cross section and produce good griping mechanism in the torsional arms, the end section was made $600 \times 600 \mathrm{~mm}$ solid square for a length of $400 \mathrm{~mm}$ from each end.

\section{Casting of Beams}

After the steel cage was erected including all longitudinal and transverse reinforcement, the beam was cast in a 
specially designed wooden and Glass Reinforced Plastic (GRP) formwork. One day after casting, the sides of the mould were disassembled leaving the bottom part bellow the beam. Six concrete cubes $(100 \mathrm{~mm})$ and six cylinders $(150 \times 300 \mathrm{~mm})$ were cast with each beam from the concrete used in the beam. A vibrating table was used for compaction of the cubes and cylinders while the beam was vibrated using an external vibrator attached to the shuttering. The beam and the cubes and cylinders were cured using wet Hessian cloth for about one week and then in room temperature for another three weeks. All cubes and cylinders were tested on the day the beam was tested to determine the cube and cylinder compressive strengths and cylinder tensile strength. Only $10 \mathrm{~mm}$ and $12 \mathrm{~mm}$ High Yield steel bars were used as longitudinal reinforcement and $10 \mathrm{~mm}$ bars were used for stirrups. From the tensile test results, the average yield stress of steel was $545 \mathrm{~N} / \mathrm{mm}^{2}$ for longitudinal reinforcement and $513 \mathrm{~N} / \mathrm{mm}^{2}$ for stirrups. Ordinary Portland cement (OPC), fine aggregate, coarse aggregate $(10 \mathrm{~mm})$ and fresh water were used in the concrete mix. Table 3 shows the average of some measured material properties.

Table 3. Measured average material properties

$\begin{array}{cccc}\begin{array}{c}\text { Beam } \\ \text { No. }\end{array} & \begin{array}{c}f_{c u} \\ \mathbf{N} / \mathbf{m m}^{2}\end{array} & \begin{array}{c}f_{y} \\ \mathbf{N} / \mathbf{m m}^{2}\end{array} & \begin{array}{c}f_{y v} \\ \mathbf{N} / \mathbf{m m}^{2}\end{array} \\ \text { TB1 } & 36 & 500 & 500 \\ \text { TB2 } & 30 & 596 & 515 \\ \text { TB3 } & 45 & 500 & 500 \\ \text { TB4 } & 29 & 565 & 525 \\ \text { TB5 } & 30 & 565 & 525\end{array}$

\section{Experimental Set-up}

Figure 5 shows the testing rig with a typical beam installed. The installation process required inserting the beam square ends into the torsional arms (Fig. 6) which are attached to shafts and bearings resting on pedestals (Fig. 7). The torsional arm ends are hooked to the strong floor by inextensible cables with hydraulic actuators and load cells. On the top face of the beam, a $1200 \mathrm{~mm}$ long spreader was installed. The spreader was centred at the mid-span of the beam with its centreline coinciding with beam centreline. The bending moment in the middle $1200 \mathrm{~mm}$ test span is acquired by applying a point load at the middle of the spreader. The torsional moment which is constant over the entire length of the beam, was applied through torsional arms clamped at the ends. The load from the spreader was transferred to the beam through two perpendicular rollers in one side while a roller and a pin were installed at the other side. This support and loading arrangements produced a simply supported condition allowing free rotation about the longitudinal axis of the beam and horizontal displacements with a rigid body motion being prevented by the pin on the top face. The test span region is mainly subjected to bending and twisting moments while outside the test span shear is added to the twisting and bending moments.

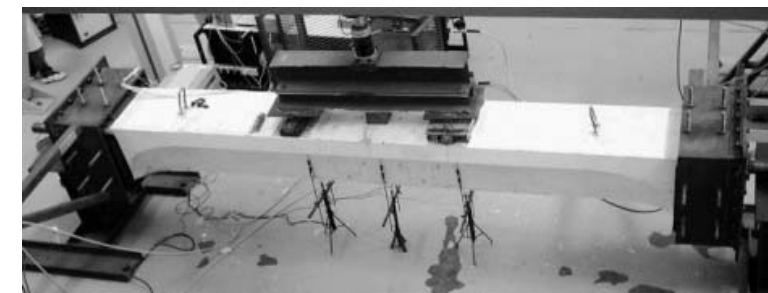

Figure 5. Test rig with a typical beam installed

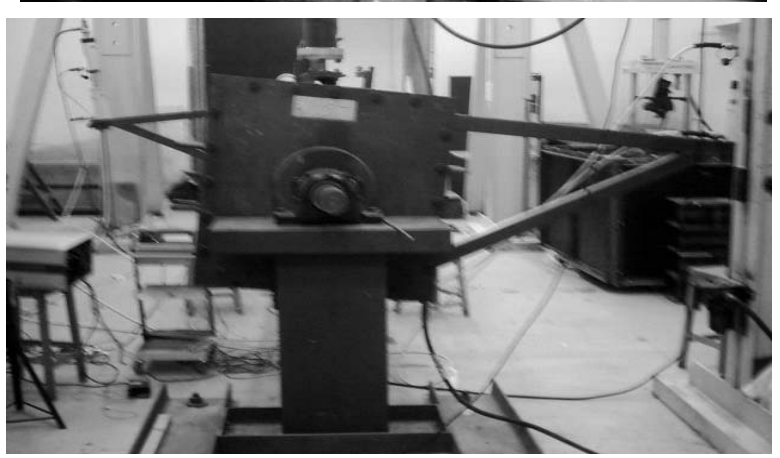

Figure 6. Torsional arm while testing

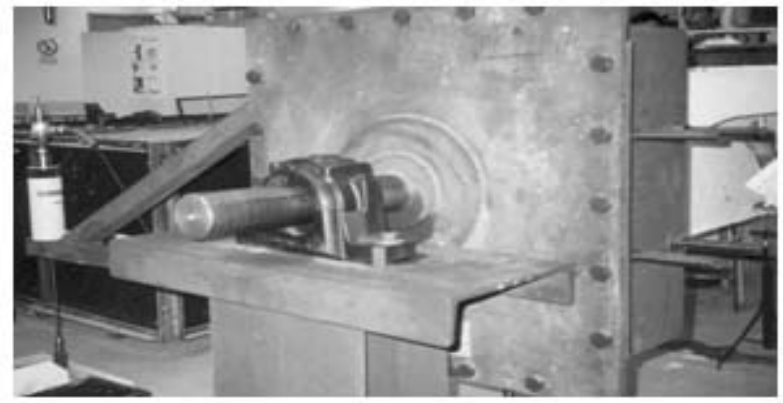

Figure 7. Close lookup of end support and torsional arm with actuator and load cell

Strains in the reinforcement were monitored using electrical resistance strain gauges. Figure 8 shows the legend

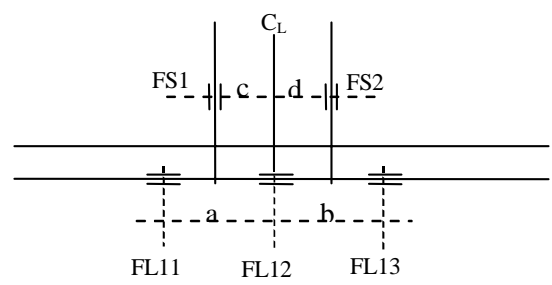

(a) Front side

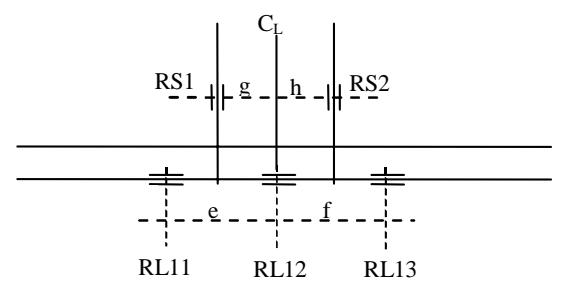

(b) Rear side

Figure 8. Legend for strain gauge locations in longitudinal and transverse steel (see Table 4) 
Table 4. Location of strain gauges (see Figure 8)

\begin{tabular}{|c|c|c|c|c|c|c|c|c|c|}
\hline $\begin{array}{l}\text { Space } \\
\text { Beam }\end{array}$ & $\begin{array}{c}\mathbf{a} \\
\mathrm{mm}\end{array}$ & $\begin{array}{c}\mathbf{b} \\
\mathrm{mm}\end{array}$ & $\begin{array}{c}\mathbf{c} \\
\mathrm{mm}\end{array}$ & $\begin{array}{c}\mathbf{d} \\
\mathrm{mm}\end{array}$ & $\begin{array}{c}\mathbf{e} \\
\mathrm{mm}\end{array}$ & $\begin{array}{c}\mathbf{f} \\
\mathrm{mm}\end{array}$ & $\begin{array}{c}\mathbf{g} \\
\mathrm{mm}\end{array}$ & $\begin{array}{c}\mathbf{h} \\
\mathrm{mm}\end{array}$ & $\begin{array}{l}\text { Vertical dist. } \\
\text { for the } \\
\text { stirrup’s }\end{array}$ \\
\hline TB1 & 260 & 260 & 130 & 130 & 260 & 260 & 130 & 130 & strain gauges \\
\hline TB2 & 128 & 128 & 64 & 64 & 128 & 128 & 64 & 64 & from the \\
\hline TB3 & 186 & 186 & 93 & 93 & 186 & 186 & 93 & 93 & $\begin{array}{l}\text { bottom of } \\
\text { the web. }\end{array}$ \\
\hline TB4 & 136 & 136 & 68 & 68 & 136 & 136 & 68 & 68 & \\
\hline TB5 & 90 & 90 & 45 & 45 & 90 & 90 & 45 & 45 & \\
\hline
\end{tabular}

Table 5. Vertical clear distances between longitudinal bars (see Fig. 9)

$\begin{array}{cccccccc}\text { Location } & \mathbf{1} & \mathbf{2} & \mathbf{3} & \mathbf{4} & \mathbf{5} & \mathbf{6} & \mathbf{7} \\ \text { Beam } & \mathrm{mm} & \mathrm{mm} & \mathrm{mm} & \mathrm{mm} & \mathrm{mm} & \mathrm{mm} & \mathrm{mm} \\ \text { TB1 } & 20 & 100 & 100 & 120 & - & 20 & 20 \\ \text { TB2 } & 20 & 80 & 80 & 100 & 100 & 20 & 20 \\ \text { TB3 } & 20 & 100 & 100 & 120 & - & 20 & 20 \\ \text { TB4 } & 20 & 100 & 100 & 120 & - & 20 & 20 \\ \text { TB5 } & 20 & 100 & 100 & 120 & - & 20 & 20\end{array}$

and arrangement of the strain gauges in the longitudinal and transverse reinforcement and Table 4 gives the location of strain gauges for each beam. At each specified location on each bar, two strain gauges were installed opposite to each other. Figure 9 shows typical locations of the longitudinal bars and Table 5 shows vertical distances

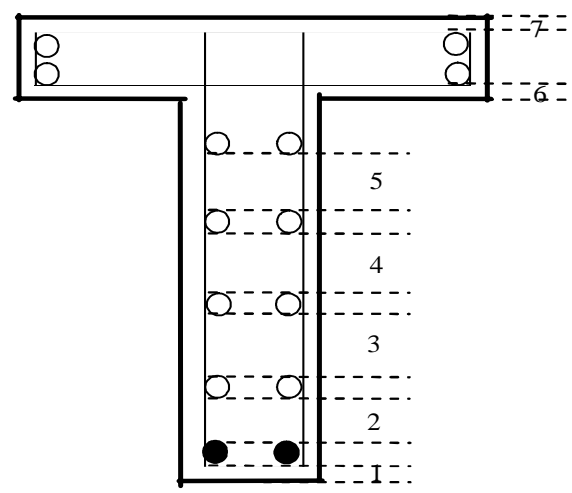

Figure 9. Typical vertical clear spaces between longitudinal bars (see Table 5)

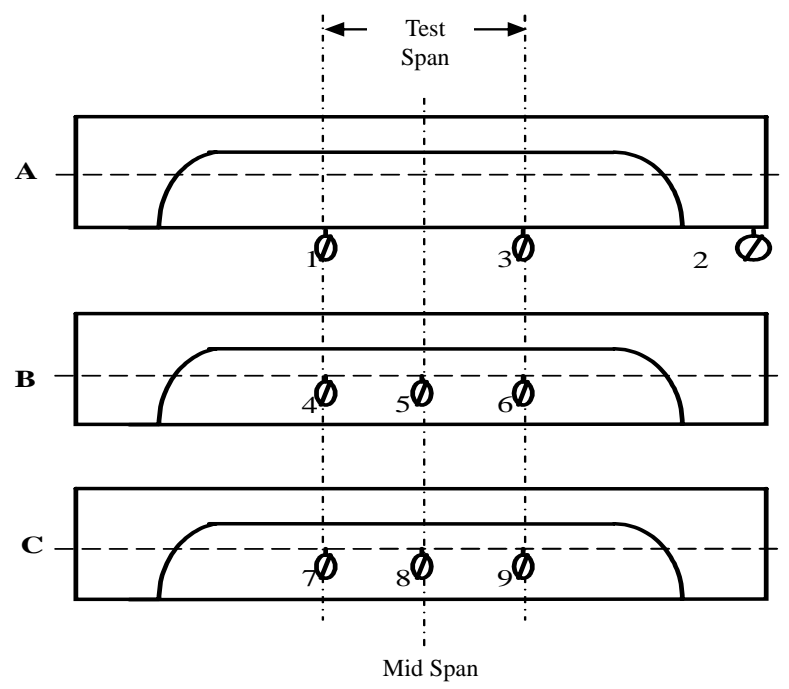

a: Bottom side transducers $\quad$ B: Front sdie transducers $\quad$ C: Rear side transducers

Figure 10. Locations of LVDT between the longitudinal bars.

Linear variable differential transducers (LVDT) were used to measure the beam deflection (Fig. 10). The concrete surface strains were measured by DEMEC (digital) gauges. All strain gauges and LVDTs were hooked to a data logger. The crack widths were measured using a crack width measuring microscope.

For each experiment, the design load was divided into load increments, $10 \%$ of the design load for each of the first three increments and 5\% for each of the following increments until failure. The first step was to zero all load cells and record instrument readings with minimum possible loads on the model. Flexural loads were normally applied before torsional load at each load level. To allow for stable deformation to take place after each load increment, an interval of about two minutes was used before recording the instrument readings. After the steel strains and displacement readings were recorded, cracks were marked and DEMEC readings were taken before the next load was applied. The beam was considered to have collapsed when it could resist no more loads. This usually happened after a major crack spiralled around the beam near the mid-span dividing the beam into two parts connected by the longitudinal reinforcement.

\section{Experimental Observations}

This section summaries the observed behaviour in the test span region of the tested T-beams at significant stages in the behaviour. The angle of crack was measured from the horizontal axis. Vertical displacement was measured at the mid-span at the bottom of the web. Strain ratios in the bottom layer of the longitudinal steel and in the transverse steel of mid-span are presented. The quoted load factor is a percentage of the experimentally measured load at each increment to the design load, L.F. $=\left(\mathrm{M}_{\mathrm{i}} / \mathrm{M}_{\mathrm{d}}+\mathrm{T}_{\mathrm{i}} / \mathrm{T}_{\mathrm{d}}\right) / 2$ including the self-weight. The failure load is a percentage of the experimentally measured failure load to the design load, $\mathrm{L}_{\mathrm{e}} / \mathrm{L}_{\mathrm{d}}=\left(\mathrm{M}_{\mathrm{e}} / \mathrm{M}_{\mathrm{d}}+\mathrm{T}_{\mathrm{e}} / \mathrm{T}_{\mathrm{d}}\right) / 2$. 
The average strain ratio in the longitudinal $\varepsilon / \varepsilon_{\mathrm{y}}$ or transverse $\varepsilon / \varepsilon_{\mathrm{yv}}$ reinforcements is the average of the measured strain at each load increment to the yield strain. At each strain-gauge location on the bar, the average of the readings from the two opposite strain gauges is considered.

$$
\text { TB1: } T_{d}=36 k N m, M_{d}=60 k N m, T_{d} / M_{d}=0.6
$$

The first few cracks were noticed at $45 \%$ of load at the bottom of the web near mid-span. The cracks were about $80 \mathrm{o}$ inclined. More cracks developed by the increase of the load until about $90 \%$ of the design load with angle of inclination being reduced to an average of $50^{\circ}$ and average width of crack of about $0.4 \mathrm{~mm}$. After this stage, few major inclined cracks started out side the test span. Near failure, prominent cracks spiralled round the beam meeting near the mid-span. The failure happened at $110 \%$ of the design load. The average crack width just before failure was about $0.6 \mathrm{~mm}$. Figure 11 shows the displacement at mid-span of the beam and Figs. 12-15 show strain ratios

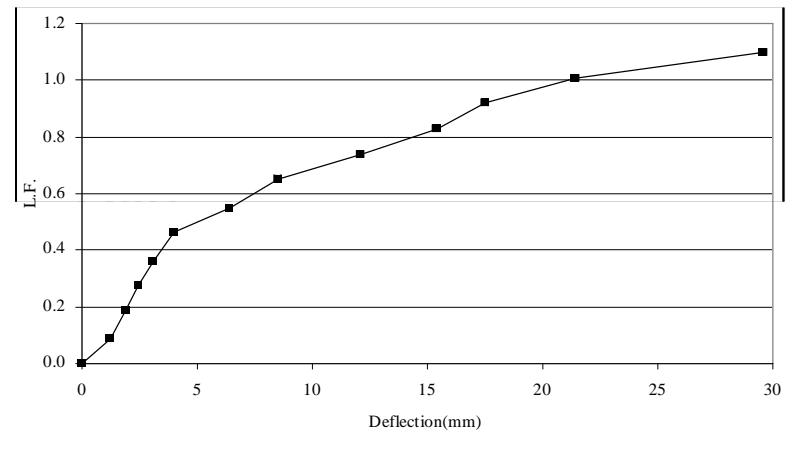

Figure 11. Deflection at mid-span (TB1)

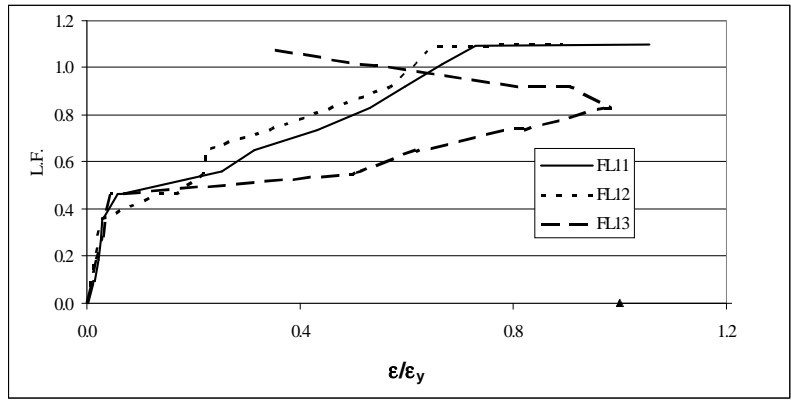

Figure 12. Front side longitudinal steel strain ratios (TB1)

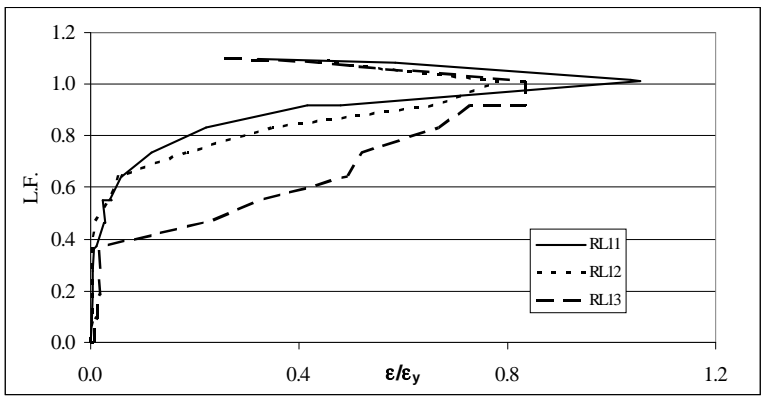

Figure 13. Rear side longitudinal steel strain ratios (TB1)

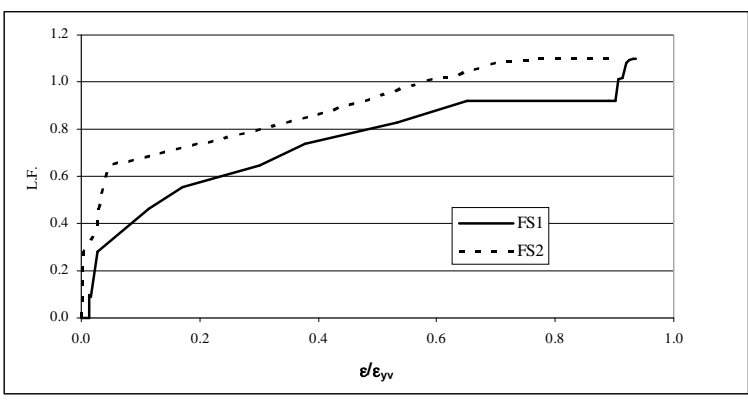

Figure 14. Front side transverse steel strain ratios $(\mathrm{TB} 1)$

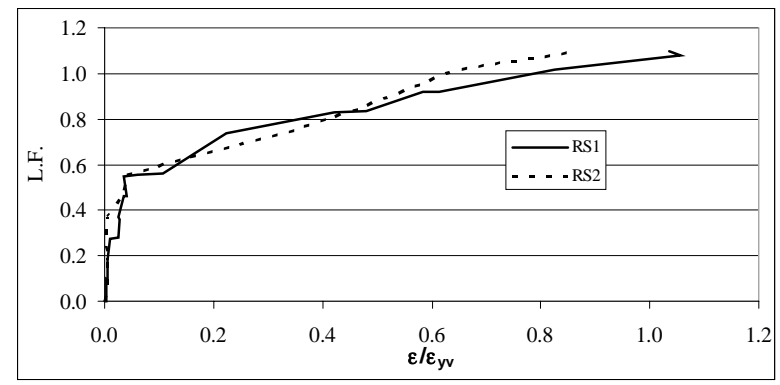

Figure 15. Rear side transverse steel strain ratios (TB1)

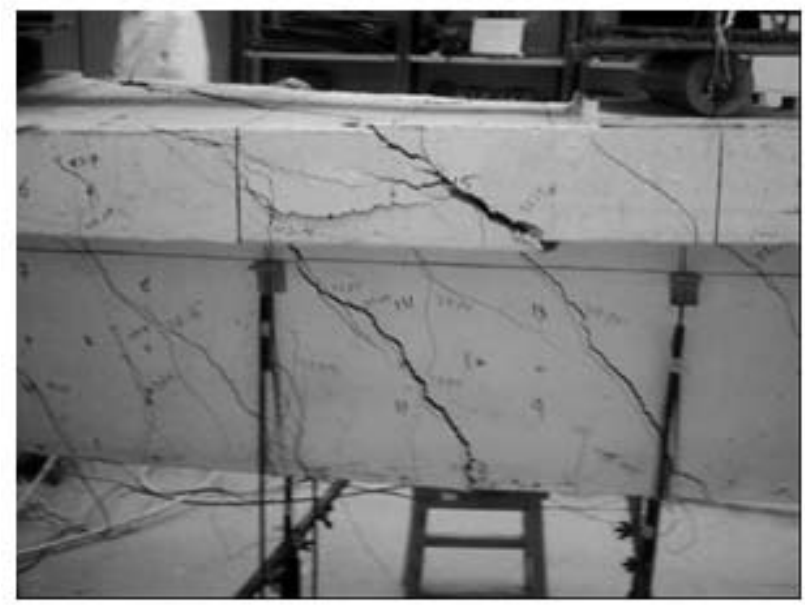

Figure 16. Crack development (TB1)

in the longitudinal and transverse reinforcement. The average strain ratio reached near failure in the longitudinal steel was 0.94 and in the stirrups, the ratio was 0.92 . Figure 16 shows crack development in the test-span of the beam.

TB2: $\mathrm{T}_{\mathrm{d}}=75 \mathrm{kNm}, \mathrm{M}_{\mathrm{d}}=100 \mathrm{kNm}, \mathrm{T}_{\mathrm{d}} / \mathrm{M}_{\mathrm{d}}=0.75$

At $40 \%$ of load, several inclined hair cracks (about $60^{\circ}$ ) were noticed in the test span region close to the bottom of the web. With the increase of the load, many fine cracks developed until about $90 \%$ of load when two major cracks widened up (45० inclination) and spiralled around the beam causing failure at $105 \%$ of the design load. The average crack width near failure load was about $0.5 \mathrm{~mm}$. 
Figure 17 shows the displacement at mid-span and Figs. 18-19 show the strain ratios in the longitudinal and transverse bars. The average strain ratio in the longitudinal bars 0.9 and in the stirrups was 0.61 . Figure 20 shows crack development in this beam.

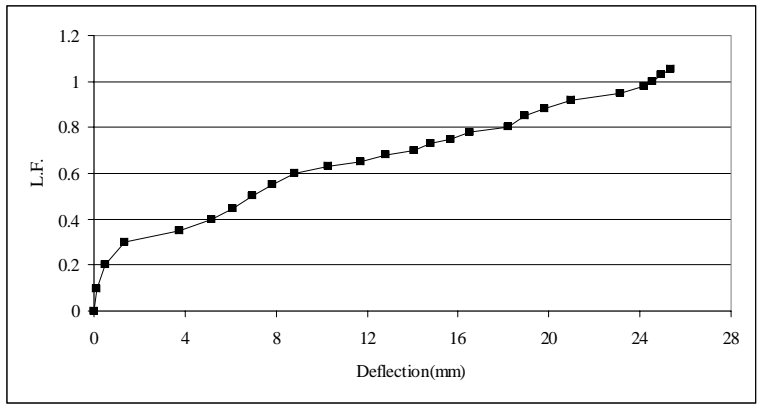

Figure 17. Deflection at midspan (TB2)

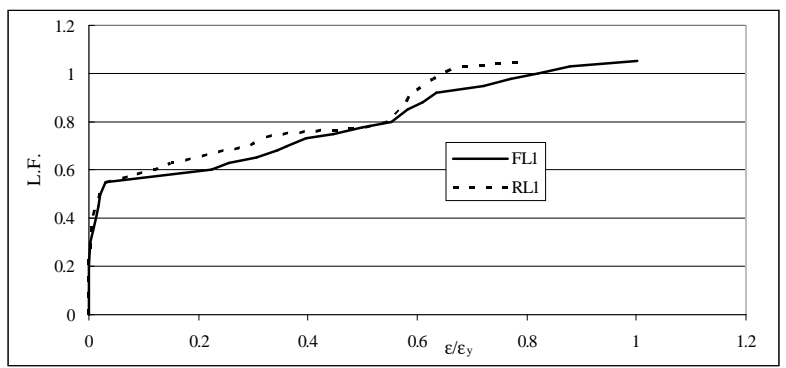

Figure 18. Longitudinal steel strain ratios (TB2)

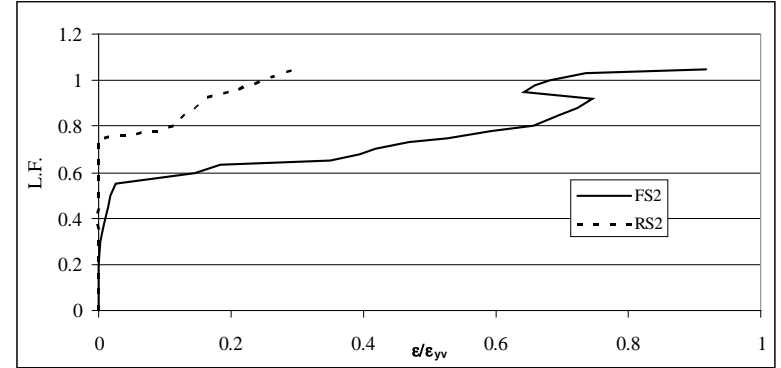

Figure 19. Transverse steel strain ratios (TB2)

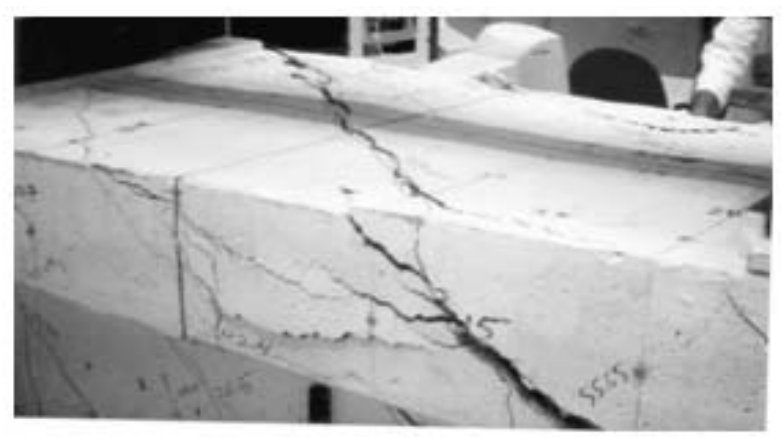

Figure 20. Crack development (TB-2)

TB3: $\mathrm{T}_{\mathrm{d}}=50 \mathrm{kNm}, \mathrm{M}_{\mathrm{d}}=60 \mathrm{kNm}, \mathrm{T}_{\mathrm{d}} / \mathrm{M}_{\mathrm{d}}=0.83$

The development of cracks in this beam was similar to that of beam TB2 with number of cracks being larger in TB3 than TB2. Failure happened at $112 \%$ of the design load. Figure 21 shows displacement at mid-span and Figs.

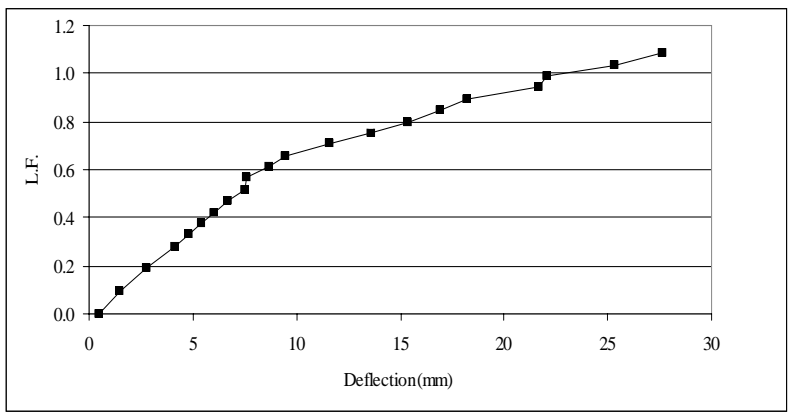

Figure 21. Deflection at midspan (TB3)

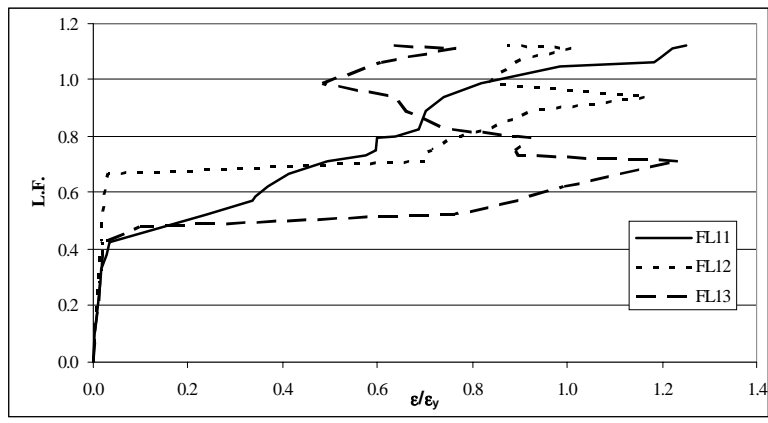

Figure 22. Front side longitudinal steel strain ratios (TB3)

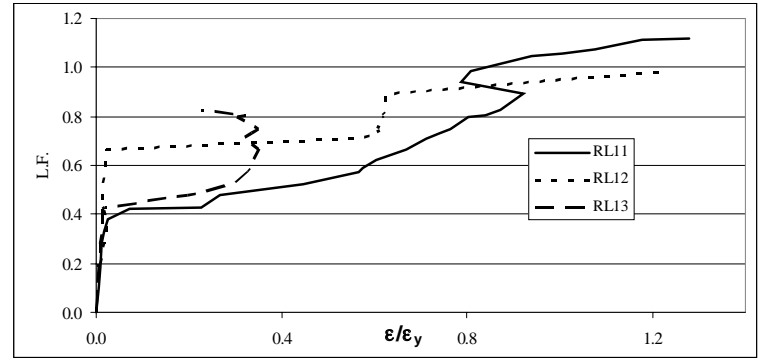

Figure 23. Rear side longitudinal steel strain ratios (TB3)

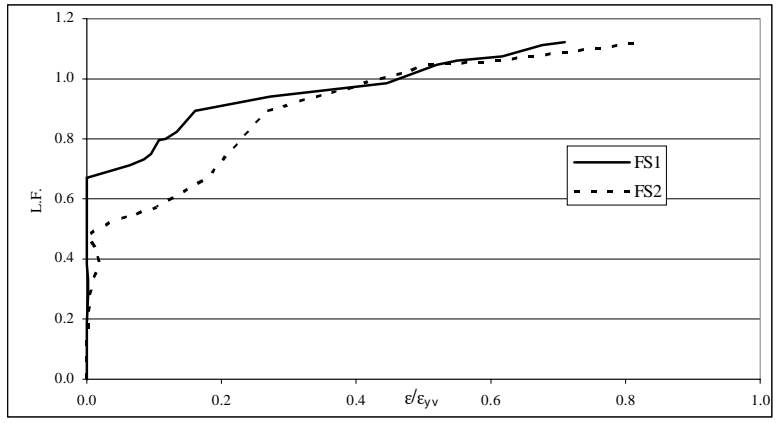

Figure 24. Front side transverse steel strain ratios (TB3)

22-25 show steel strain ratios in the longitudinal and transverse steel. Figure 26 shows crack development in this beam. The average width of cracks near failure was $0.45 \mathrm{~mm}$ and the average strain ratio near failure was 0.91 in the longitudinal steel and 0.85 in the stirrups. 
The Journal of Engineering Research Vol. 4, No.1 (2007) 23-36

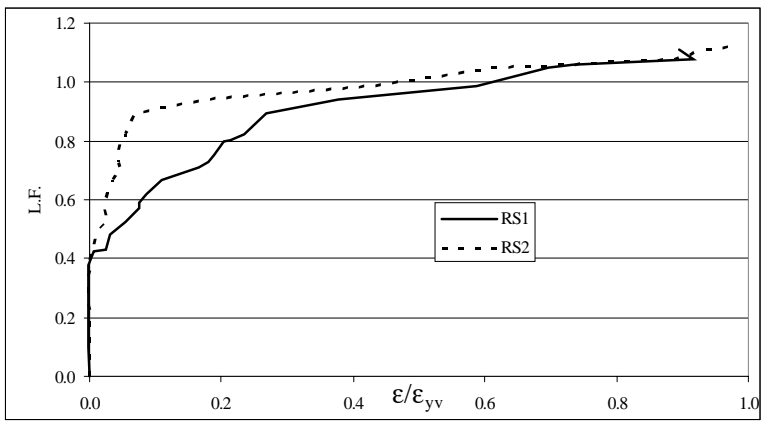

Figure 25. Rear side transverse steel strain ratios (TB3)

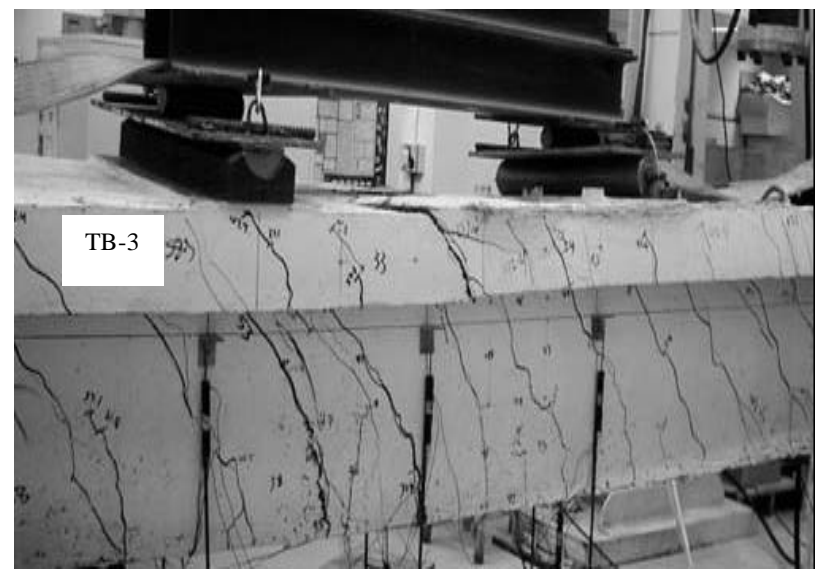

Figure 26. Crack development (TB3)

TB4: $\mathrm{T}_{\mathrm{d}}=72 \mathrm{kNm}, \mathrm{M}_{\mathrm{d}}=72 \mathrm{kNm}, \mathrm{T}_{\mathrm{d}} / \mathrm{M}_{\mathrm{d}}=1.0$

At $25 \%$ of load, few inclined cracks (about $45^{\circ}$ ) started in the lower part of the web. The number of cracks increased largely with the increase of the load but the width was smaller than in the previous beams. The beam failed at $100 \%$ of the design load with few cracks widened slightly larger than the others did. Figure 27 shows displacement at mid-span and Figs. 28-31 show steel strain ratios in the longitudinal and transverse steel. Figure 32 shows crack development in this beam. The average width of cracks near failure was $0.4 \mathrm{~mm}$ and the average strain ratio near failure was 1.05 in the longitudinal steel and 0.94 in the stirrups.

TB5: $\mathrm{T}_{\mathrm{d}}=108 \mathrm{kNm}, \mathrm{M}_{\mathrm{d}}=72 \mathrm{kNm}, \mathrm{T}_{\mathrm{d}} / \mathrm{M}_{\mathrm{d}}=1.5$

This beam behaved in a similar manner like TB4 but

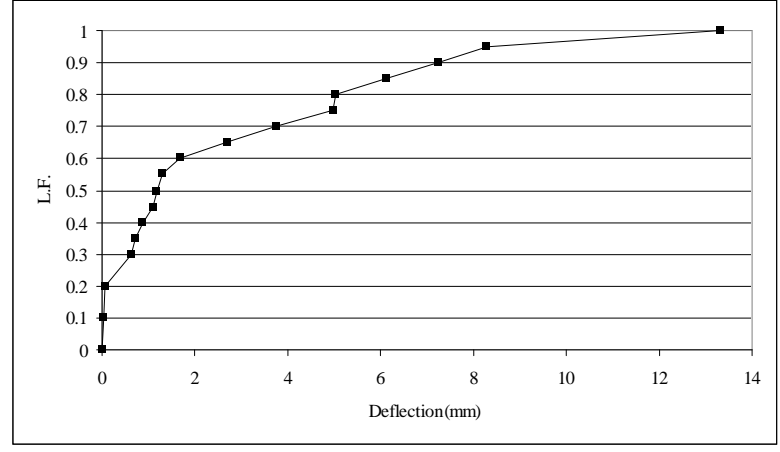

Figure 27. Deflection at midspan (TB4)

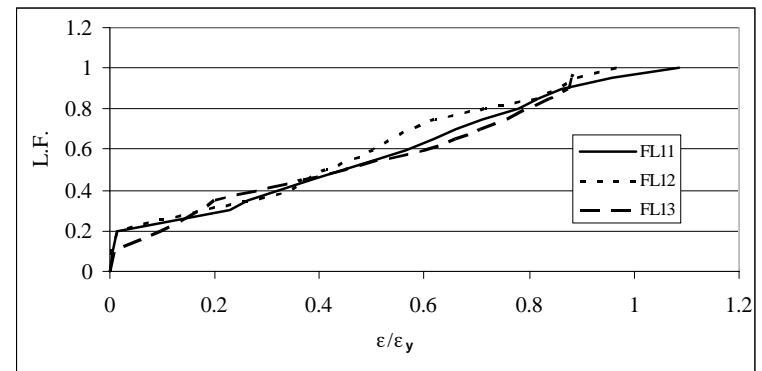

Figure 28. Front side longitudinal steel strain ratios (TB4)

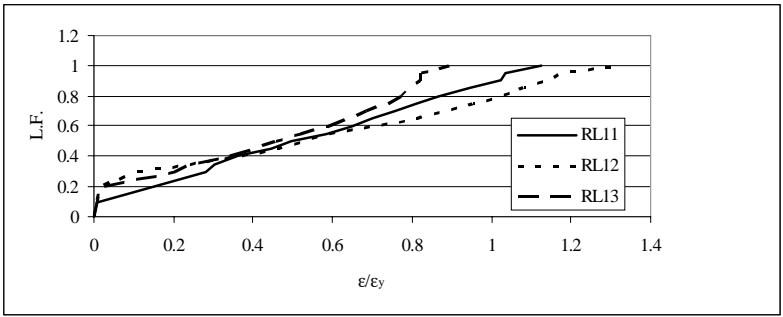

Figure 29. Rear side longitudinal steel strain ratios (TB4)

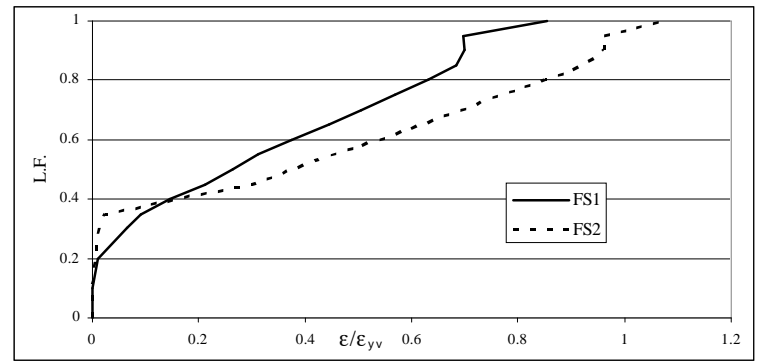

Figure 30. Front side transverse steel strain ratios (TB4)

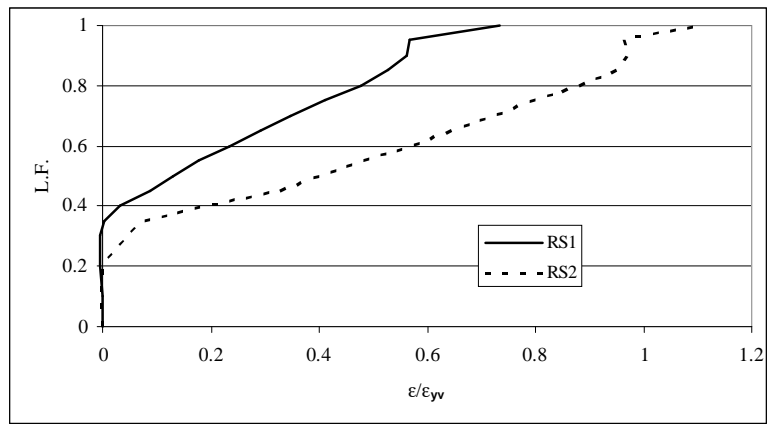

Figure 31. Rear side transverse steel strain ratios (TB4)

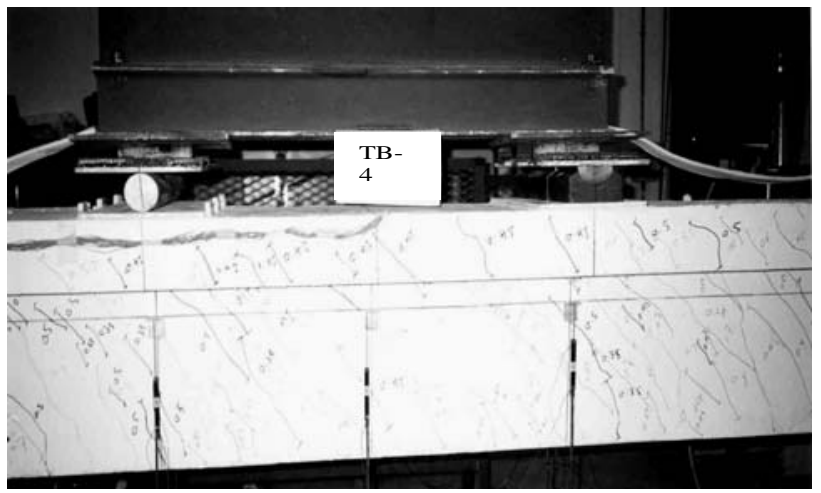

Figure 32. Crack development (TB4) 
with larger number and finer cracks. There was no major cracks but the beam failed by losing strength due to the large number of cracks at a load of $98 \%$ of the design load. Figure 33 shows displacement at mid-span and Figs. 34-35 show steel strain ratios in the longitudinal and transverse steel. Figure 36 shows crack development in this beam. The average width of cracks near failure was $0.3 \mathrm{~mm}$ and the average strain ratio near failure was 1.04 in the longitudinal steel and 0.92 in the stirrups.

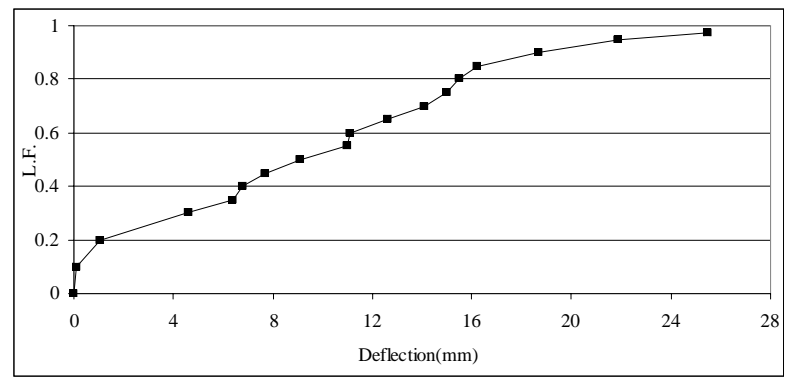

Figure 33. Deflection of midspan (TB5)

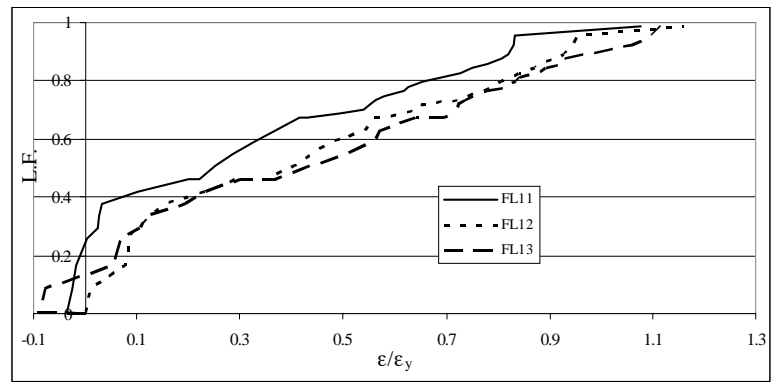

Figure 34. Front side longitudinal steel strain ratios (TB5)

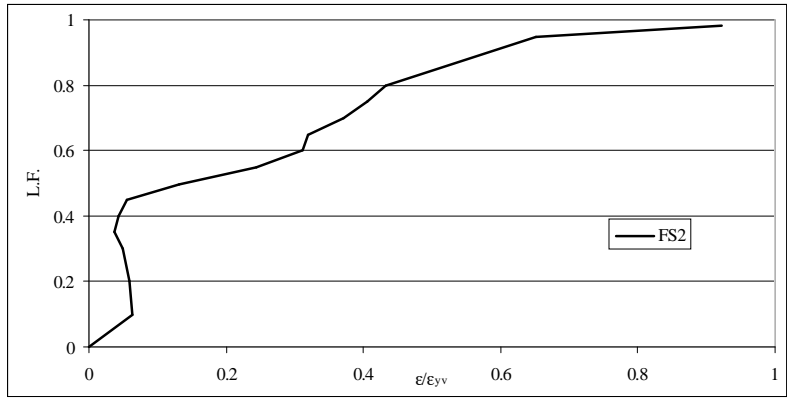

Figure 35. Front side transverse steel strain ratios (TB5)

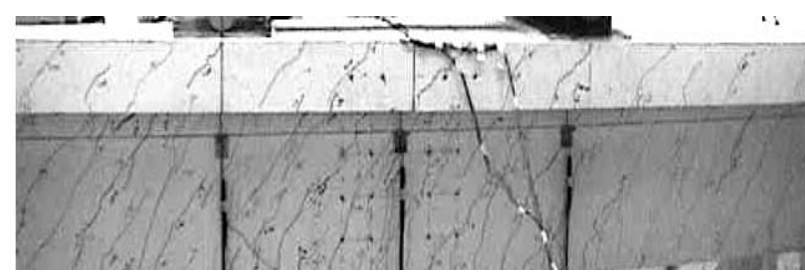

Figure 36. Crack development (TB5)

\section{Discussion of Results}

In all beams, the longitudinal and transverse steel either yielded or reached nearly the yield strain. This is to be expected since the beams were designed according to the lower bound theory of plasticity. Beams loaded dominantly in bending (ie. low $T_{d} / M_{d}$ ratio) showed more ductile behaviour than those with large $T_{d} / M_{d}$ ratios (Table 7). In general, all beams showed ductile behaviour as expected for under-reinforced sections. Furthermore, there was no crushing of concrete before yielding of steel. All beams failed near their design loads for all variations of $T_{d} / M_{d}$ ratios (Column 3 of Table 6).

Table 6. Experimental/design failure load ratios

\begin{tabular}{ccc} 
Load & $\mathbf{T}_{\mathbf{d}} / \mathbf{M}_{\mathbf{d}}$ & $\mathbf{L}_{\mathbf{e}} / \mathbf{L}_{\mathbf{d}}$ \\
Beam & Ratio & Ratio \\
TB1 & 0.60 & 1.1 \\
TB2 & 0.75 & 1.05 \\
TB3 & 0.83 & 1.12 \\
TB4 & 1.00 & 1.00 \\
TB5 & 1.50 & 0.98 \\
\multicolumn{2}{c}{ Average } & 1.05
\end{tabular}

Table 7. Load-crack and displacement measurement

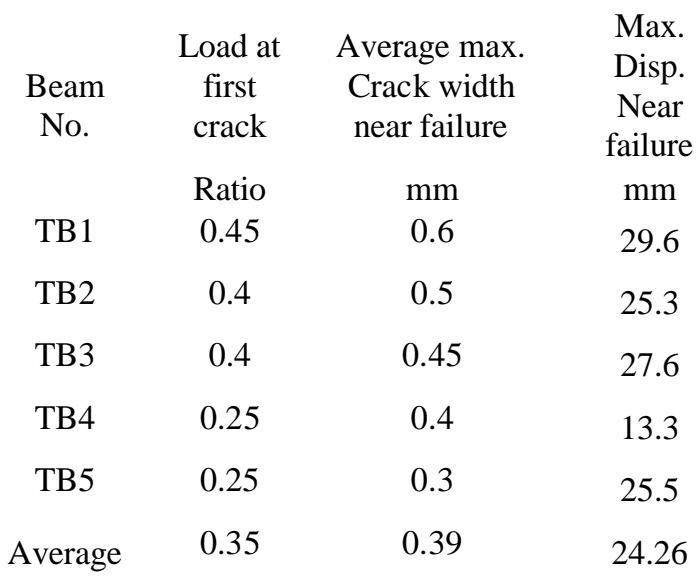

Beams loaded dominantly in bending $\left(\mathrm{T}_{\mathrm{d}} / \mathrm{M}_{\mathrm{d}}<1\right)$ had vertical cracks started to develop first at the bottom of the web, then progressed as inclined cracks in succeeding load increments until reaching the flange at about $80 \%$ of the design load.

Beams loaded dominantly in torsion $\left(T_{d} / M_{d}>1\right)$ had inclined cracks started at mid-depth in the web before they extend into the bottom of the web. Generally, cracks formed earlier in beams loaded dominantly in torsion $\left(T_{d} / M_{d}>1\right)$ than other beams. In these beams, cracking started at a load as early as $25 \%$ of design load, while in other beams, they started at about $40 \%$ of design. 
In beams where bending was dominant, the cracks in the test span were less in number and wider than in the beams where torsion was dominant. This is due to the fact that torsion was constant throughout the entire length while maximum bending moment existed over a small distance at the middle of the beam.

\section{Conclusions}

From the results shown in this paper, it can be concluded that the direct design method produces a safe design for reinforced concrete T-beams under combined loading of bending and torsion. Most of the beams failed near design loads and undergone ductile behaviour until failure. The reinforcement yielded or reached near yield when the design load was approached. The direct design method required less longitudinal reinforcement than the BSI code and close to the reinforcement required by the ACI code. It required less transverse reinforcement than both BSI and ACI codes.

\section{References}

Abdel-Hafez Laila, M., 1986, "Direct Design of Reinforced Concrete Skew Slab," PhD Thesis, University of Glasgow, 1986.

ACI committee 318, "Building Code Requirements for structural Concrete (ACI318M-02) and Commentary (ACI318RM-02)," American Concrete Institute, Farmington Hills, Mich. 48333-9094, USA.

Ali Alnuaimi and Bhatt, P., 2004a, "Direct Design of Hollow Reinforced Concrete Beams -Part I: Design Procedure," Structural Concrete Journal, Vol. 5(4), pp. 139-146.

Ali Alnuaimi and Bhatt. P., 2004b, "Direct Design of Hollow Reinforced Concrete Beams -Part II: Experimental Investigation," Structural Concrete Journal, Vol. 5(4), pp. 147-160.

Bhatt, P. and Bensalem, A., 1996a, "Behaviour of Reinforced Concrete Flat Slab Over Column Support using Nonlinear Stress Field Design," Structural Engineering Review, Vol. 8(2-3), pp. 201 - 212.

Bhatt, P. and Bensalem, A., 1996b, "Use of Non-elastic Stress in the Design of Reinforced Concrete Deep Beams," Structural Engineering Review, Vol.8(2-3), pp. $213-225$.

Bhatt, P. and Ebireri, J. O., 1989, "Direct Design of Beams for Combined Bending and Torsion," Stavebnicky Casopis, Vol. 37(4), pp. 249-263.

Bhatt, P. and Mousa, J., 1996, "Tests on Concrete Box Beams under Non-monotonic Loading," Structural Engineering Review, Vol. 8(2-3), pp. 227 - 235.

BS8110, 1997, "Structural Use of Concrete, Part1: Code of Practice for Design and Construction", British
Standard Institution, 389Chiswick High Road, London, W4 4AL.

Elarabi, H., 1999, "Application of the Direct Design Method on Reinforced Concrete Beams subjected to Combined Torsion, Bending and Shear," Building and Road Research Journal, University of Khartom, Vol. 2, pp. 47-56.

El-Hussein, E. A., 1994, "Finite Element and Direct Design Method in Combined Torsion, Bending and Shear of Reinforced Concrete," Computational Structural Engineering for Practice," Civil-Comp Ltd, Edinburgh, Scotland, pp. 165-171.

El-Nuonu, G. F. R., 1985, "Design of Shear Wall-floor Slab Connections," PhD Thesis, University of Glasgow, UK.

Farmer, L. E. and Ferguson, P. M., 1967, "Shear and Torsion", ACI Journal, pp. 757-65.

Gurfinkel, G. and Fonseca, F., 1996, "Designing T-Beams for less Ductility than required by ACI", ACI Structural Journal, Vol. 93(S12), pp. 116-127.

Hago, A. and Bhatt P., 1986, "Tests on Reinforced Concrete Slabs Designed by Direct Design Procedure," ACI Journal, Vol. 83-79(6), No.6, Nov.Dec., 1986, pp. 916-924.

Kemp, K. O., 1971, "Optimum Reinforcement in a Concrete Slab Subjected to Multiple Loadings," Publications of the International Association of Bridge and Structural Engineering, pp. 93 - 105.

Kirk, D. W. and Loveland, N. C., 1972, "Unsymmetrically Reinforced T-Beams Subject to Combined Bending and Torsion," Paper No. 69-44, ACI Journal, pp. 49299.

Kotsovos, M. D., Bobrowski, J., and Eibl, J., 1987, "Behaviour of Reinforced Concrete T-beams in Shear," The Structural Engineer, Vol. 65B(1), pp. 1-10. Memon, M., 1984, "Strength and Stiffness of Shear Wallfloor Slab Connections," PhD Thesis, University of Glasgow, UK.

Morley, C. T. and Gulvanessian, H., 1977, "Optimum Reinforcement of Concrete Slab Elements", Proc. Institution of Civil Engineers, Vol. 63(2), pp. 441-454.

Nawy, E. G. and Potyondy, J. G., 1971, "Flexural Cracking Behaviour of Pretensioned I- and T-Beams," ACI Journal, pp. 355-360

Nielsen, M. P., 1974, Optimum Design of Reinforced Concrete Shells and Slabs," Structural Research Laboratory, Technical University of Denmark, Report NR.R44, pp.190-200.

Rahal, K. N. and Collins, M. P., 2003, "Experimental Evaluation of ACI and AASHTO-LFRD Design Provisions for Combined Shear and Torsion," ACI Structural Journal, Vol. 100(3), pp. 277 - 282.

Zararis, P. D. and Penelis, G. Gr., 1986, "Reinforced Concrete T-beams in Torsion and Bending," ACI Journal, Title No. 83-17, pp. 145-55. 


\section{Appendix}

Example: Design of $\mathrm{T}$-beams using Direct Design Method

TB3:

$$
\mathbf{T}_{\mathrm{d}}=\mathbf{5 0} \mathrm{kN} \cdot \mathrm{m}
$$

$M_{d}=60$ kN.m

$\mathbf{T}_{\mathrm{d}} / \mathbf{M}_{\mathrm{d}}=\mathbf{0 . 8 3}$

See Figs: 1 and 2.

- Gross-sectional area (Fig. A1):

$\mathrm{A}=600 \times 150+200 \times 450=180000 \mathrm{~mm}^{2}$

- Depth of neutral axis from top of flange:

$600 \times 150 \times 150 / 2+200 \times 450 \times 375=(600 \times 150+200 \times 450) \bar{X}$

$\bar{X}=225 \mathrm{~mm}$

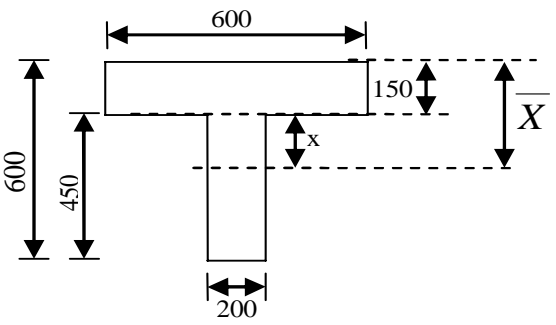

For torsion assume 50mm effective $\mathrm{w}$ all thickness (Fig. A2):

- Area of section within the shear flow centerline,

$A_{o}=100 \times 550+150 \times 425=11.875 \times 10^{4} \mathrm{~mm}^{2}$

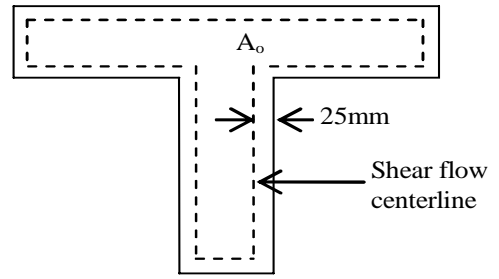

Fig. A2: Shear flow centerline

- $\quad$ Moment of inertia, $I=\frac{1}{3}\left[600 \times 225^{2}+200(600-225)^{3}-75^{3}(600-200)\right]=5.7375 \times 10^{4} \mathrm{~mm}^{4}$

- Normal stress due to bending at the centroid of each level: $\sigma_{i}=\frac{M y_{i}}{I}, i=$ level reference and $\mathrm{y}=$ distance between level centroid and neutral axis (Column 3 of Table A1).

- $\quad$ Assume Ó $_{\mathrm{yi}}=0$, No out of plane bending (Column 4 of Table A1).

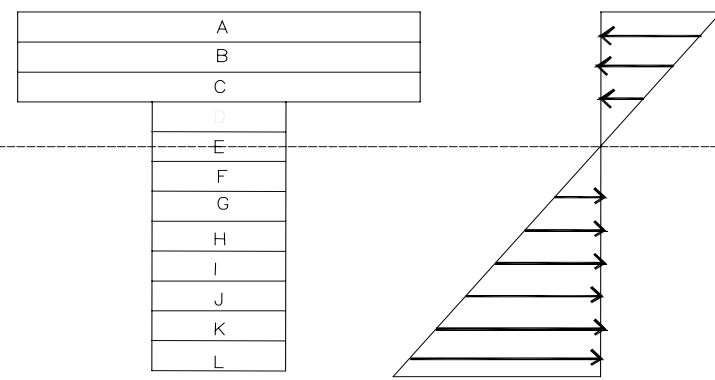

Fig. A3: Levels (regions) in the cross section and normal stress.

- $\quad$ Calculate shear stre ss due to torsion, wall thickness 50mm (Column 5 of Table A1):

$\tau_{x y}=\frac{T}{2 t A_{O}}=\frac{50 \times 10^{6}}{2 \times 50 \times 11.875 \times 10^{4}}=4.21 \mathrm{~N} / \mathrm{mm}^{2}$

- Calculate ó $o_{\mathrm{xi}} / \hat{\mathrm{o}}_{\mathrm{xy}}$ and ó $_{\mathrm{yi}} / \hat{\mathrm{o}}_{\mathrm{xy}}$ (columns 6 and 7 of Table A1).

- Select the design case from the boundary graph for Nielsen's design equations shown in Fig. A4 (Column 8 of Table A1).

- Calculate forces in the longitudinal direction per unit length: $\quad N_{X}^{S}=N_{X}+\left|N_{x y}\right|$ (Column 9 of Table A1).

- Calculate forces in the transverse direction per unit length: $\quad N_{y}^{S}=N_{y}+\left|N_{x y}\right|$ (Column 10 of Table A1).

- Calculate steel areas for each region in the $x$ and $y$ di rections, assume $f_{y}=f_{y v}=500 N / m^{2}$ (columns 11 and 12).

- Select the number of bars and bar size based on the available sizes and required areas.

- Detail calculation for level A is shown below Table A1. 
Table A1: Calculation of reinforcement for Example A

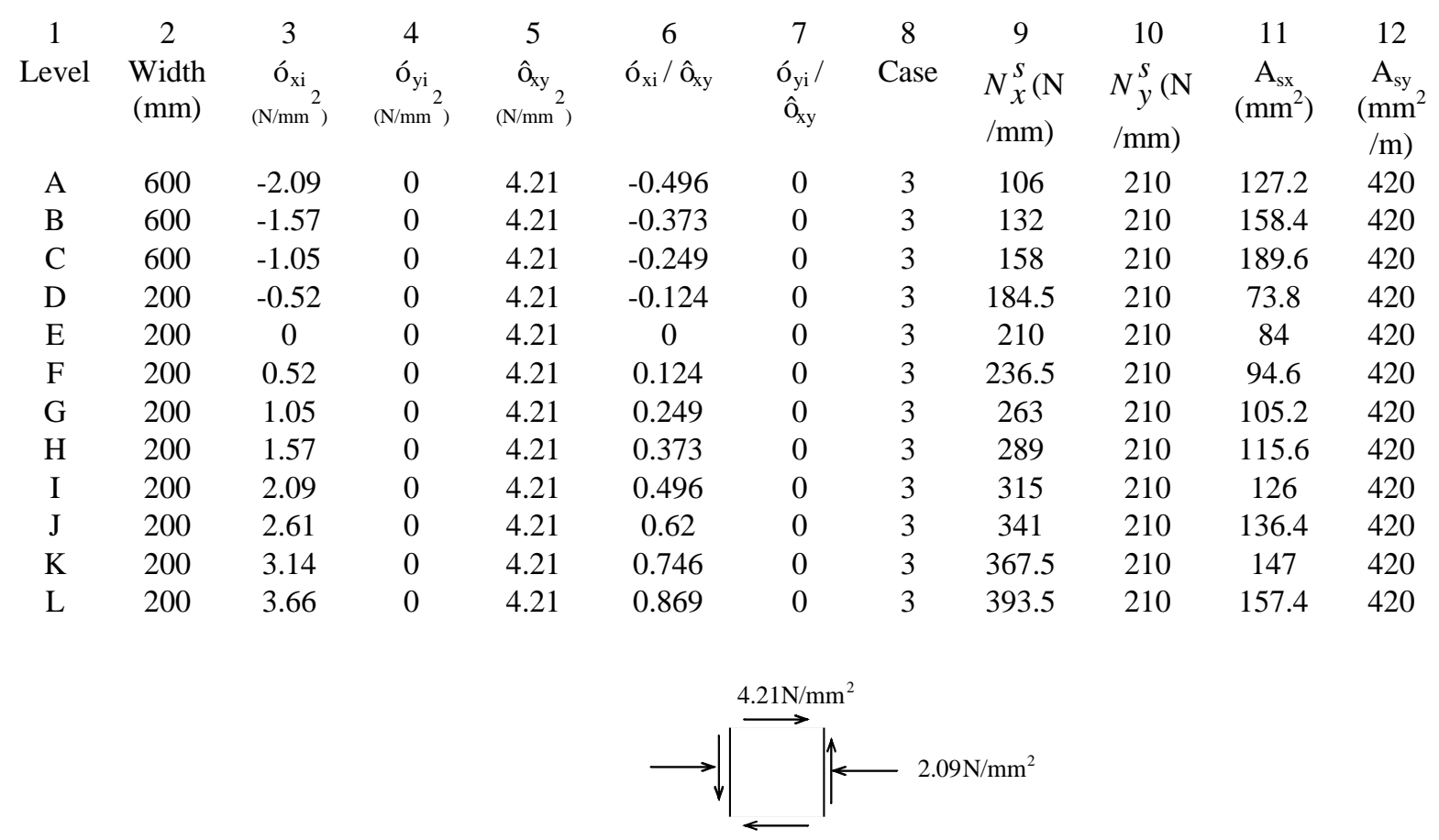

Detail Calculation for level A:

Col. 3: $\sigma_{A}=\frac{-M y_{A}}{I}=\frac{-60 \times 10^{6} \times 200}{5.7375 \times 10^{9}}=-2.09 \mathrm{~N} / \mathrm{mm}^{2} \quad$ (C)

Col. 8: From columns 6 \& 7: we have: ó $_{x i} / \hat{o}_{x y}=-0.496$ and ó $_{\mathrm{yi}} / \hat{\mathrm{o}}_{\mathrm{xy}}=0$ ? from Fig A4 the location of this point lies in the region of case 3.

Col. 9: The force in x direction cal culated as given in Fig. A 4: $N_{X}^{S}=N_{X}+\left|N_{x y}\right|=50(-2.09+4.21)=106 \mathrm{~N} / \mathrm{mm}$. Col. 10: The force in y direction calculated as given in Fig. A 4:

$N_{y}^{s}=N_{y}+\left|N_{x y}\right|=50(0+4.21)=210 \mathrm{~N} / \mathrm{mm}$

Col. 11: The steel area in x direction is given by: $A_{X}=\frac{N_{X}^{S}}{f_{y}}=\frac{106}{500}=0.212 \mathrm{~mm}^{2} / \mathrm{mm} \Rightarrow=0.212 \times 600=127.2 \mathrm{~mm}^{2}$.

Col. 12: The steel area in y direc tion is given by: $A_{y}=\frac{N_{y}^{S}}{f_{y v}}=\frac{210}{500}=0.42 \mathrm{~mm}^{2} / \mathrm{mm} \Rightarrow=0.42 \times 1000=420 \mathrm{~mm}^{2} / \mathrm{m}^{2}$ 


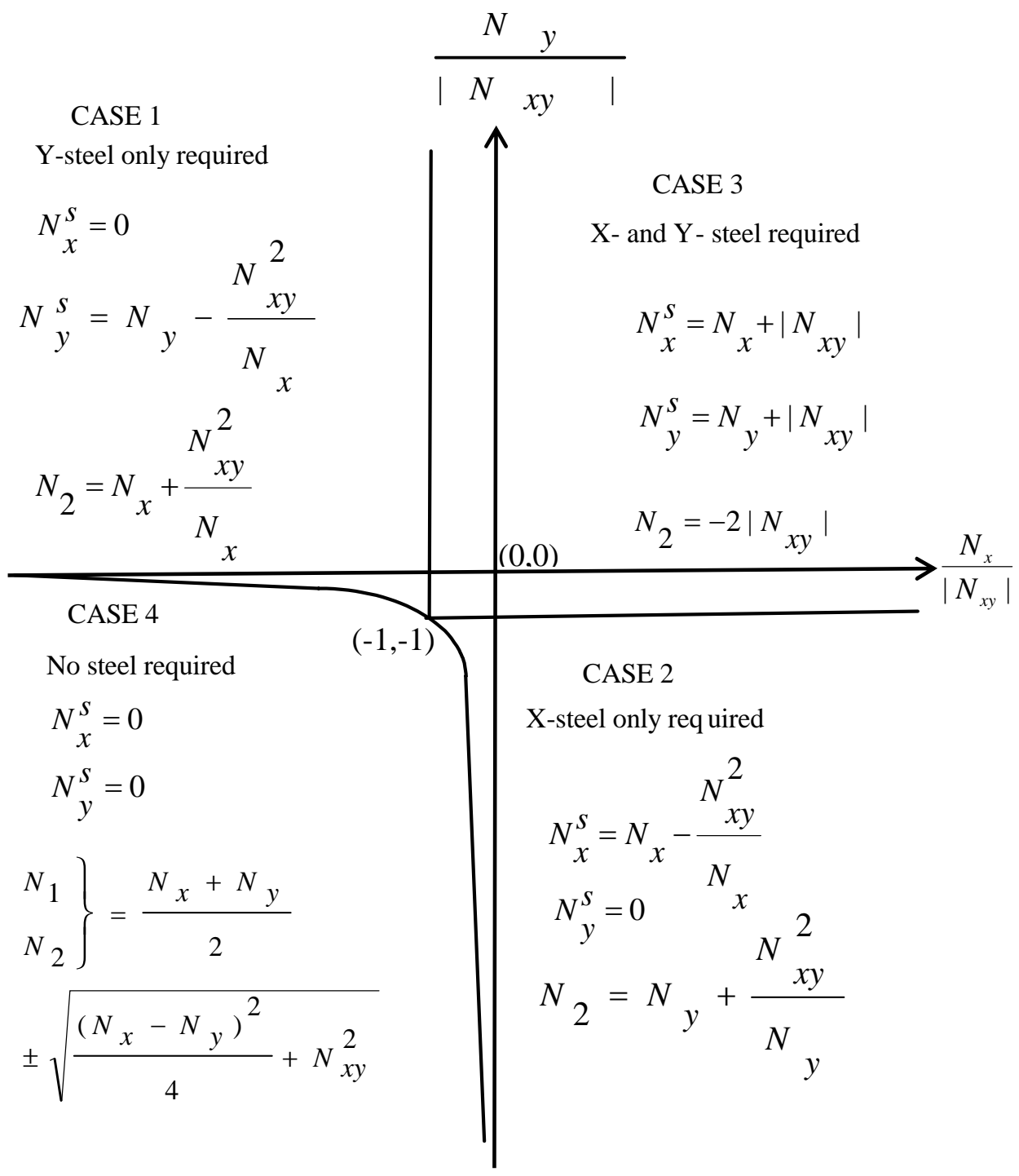

Fig. A4: Boundary graph for Nielson's 2D design equations 